\title{
Reuse of Treated Wastewater in the Manufacture of Concrete: Major Challenge of Environmental Preservation
}

\section{Fatima Zahra Bouaich ( $\square$ bouaich.isbtp@gmail.com )}

university sidi mohamed ben abdellah, faculty of sciences Dhar El Mahraz, Fez

\section{Walid Maherzi}

IMT lille Douai

\section{Fadoua Elhajjaji}

University sidi mohamed ben abdellah, faculty of science Dhar El Mahraz

\section{Nor-Edine Abriak}

IMT Lille Douai

Mahfoud Ben Zarzour

IMT Lille Douai

\section{Mustapha Taleb}

University sidi mohamed ben abdellah, Faculty of science Dhar El Mahraz

\section{Zakia Rais}

University sidi mohamed ben abdellah, Faculty of science Dhar El Mahraz

\section{Research Article}

Keywords: Reuse, treated wastewater, concrete, environment, drinking water, groundwater, physicomechanical properties.

Posted Date: February 15th, 2021

DOl: https://doi.org/10.21203/rs.3.rs-173606/v1

License: (a) (1) This work is licensed under a Creative Commons Attribution 4.0 International License. Read Full License

Version of Record: A version of this preprint was published at Environmental Science and Pollution Research on August 18th, 2021. See the published version at https://doi.org/10.1007/s11356-021-15561-3. 


\section{Abstract}

This work concerns the reuse of treated wastewater from Er-Rachidia wastewater treatment plant (WWTP) in the mixing of ordinary B25 concrete, in order to reduce the overexploitation of groundwater, avoid its discharge into watercourses and reduce the risk of environmental pollution due to its mineral and organic matter load. In this respect, Tree types of mixing water were used in this study: Drinking Water (DW), Groundwater (GW) and Treated Wastewater (TW). The results recorded for each type of mixing water, in the fresh and hardened state of concretes, are then compared with the requirements of the standards. The obtained results show that the treated wastewater does not have any adverse effect upon the quality of the concrete; it has shown an improvement of the mechanical resistance from the first stage, a similar density, setting time and porosity and a slight decrease of the workability compared with the control concrete. A Oneway analysis of variance (ANOVA) at the $5 \%$ significance level indicated no significant difference between concrete samples produced and cured with treated wastewater and control samples at ages 7, 14, 28 and 90 days. Throughout this study the substitution of drinking water by treated wastewater will help to minimize the need for its use. Additionally, it saves drinking water for consumption and makes wastewater treatment plants more economically attractive, together with other similar goals for sustainable development.

\section{Introduction}

The scarcity of water resources and the degradation of their quality is a major challenge for the twenty-first century. Drought and lack of clean water have become common concerns in many arid and semi-arid regions of the world. The United Nations (UN) World Water Development Report (WWDR) predicted that nearly 6 billion peoples would suffer from clean water scarcity by 2050; while at present, slightly less than one half of the global population, 3.6 billion people or $47 \%$, live in areas where freshwater is not enough (WWAP 2018). Therefore, in some applications, it appears important to preserve natural water resources that can be substituted by alternative water resources; treated wastewater and rainwater are one of these resources. In terms of volume, concrete is the second most consumed product in the world after water with 10 billion $\mathrm{m}^{3}$ per year, an average consumption of $1.5 \mathrm{~m}^{3}$ per person (Sarrazin and Lafarage. 2011). According to studies carried out by the National Office of Drinking Water of Morocco, the demand of drinking water of a Moroccan city in a semi-arid region, like Er-Rachidia, will evolve from $12.2 \mathrm{Mm}^{3}$ / year in 2018 to $16.7 \mathrm{Mm}^{3}$ by 2050 (ABH 2018). Moreover, the making of a cubic meter of concrete consumes about 150 liters of drinking water (LafargeHolcim 2016; Kucche et al. 2015), and the huge quantities of fresh water used for washing mixer trucks, concrete pumps, equipment, aggregates, curing concrete and ready-mix concrete. To cope with this situation, various lines of research have been developed to protect this drinking water and natural water resources by proposing other alternatives. One of those alternatives is to recycle treated wastewater for a partial or total substitution of drinking water in the manufacture of concrete (Kosmatka et al. 2002; Renaud et al. 2008). This research has been developed to address the issue of the conservation of drinking water by recycling treated wastewater of Er-Rachidia wastewater treatment plant (WWTP) in concrete. The experimental program is based on a comparative study of the physico-mechanical properties of ordinary B25 concretes using three types of mixing water: drinking water (DW), groundwater (GW) and treated wastewater (TW) in order to qualify the use of the treated wastewater from Er-Rachidia WWTP in concrete. 


\section{Materials And Methods}

The mixing waters used in this investigation were sampled from the Moroccan city Er-Rachidia. The city of ErRachidia located at the gateway to the great Moroccan Sahara, $320 \mathrm{~km}$ south of Meknes. It is characterized by a pre-Saharan climate in the north and desert to the south, where water has become one of the few resources in this region.

\section{Materials}

\section{Mixing water}

To produce B25 ordinary concrete, three types of mixing water were used:

- DW: Drinking water from the city of Er-Rachidia.

- TW: Wastewater Processed from the Er-Rachidia wastewater treatment plant.

- GW: Groundwaters of the Aïn El Atti artesian aquifer, 25 kilometers north of the city of Erfoud.

All waters were characterized by the measurement of the physico-chemical parameters (hydrogen potential, $\mathrm{pH}$, conductivity $\mathrm{Y}$, temperature $\mathrm{T}^{\circ}$, chemical oxygen demand COD, biological oxygen demand after 5 days BOD5, Nitrates $\mathrm{NO}^{-}$, Nitrites $\mathrm{NO}^{-}$, Suspended matter MES), the trace elements (Potassium (K), Zinc (Zn), Phosphorus (P), Calcium (Ca), Magnesium (Mg), Sodium ( $\mathrm{Na})$, Iron ( $\mathrm{Fe})$, Lead (Pb)) and the bacteriological parameters (CF Faecal Coliforms, CT totals and the material charge organic biodegradable); then compared to the allowable limits of these parameters for the water used in the production of concrete.

The temperature, the conductivity and the $\mathrm{pH}$ were carried out on sampling sites. The $\mathrm{pH}$ measurements, the conductivity and the BOD5 are analyzed respectively by a HACH model Sension2 type $\mathrm{pH}$ meter and a $\mathrm{HACH}$ model Sension 5 type conductivity meter, and a VELP SCIENTIFICA type 6D range pressure sensor 2000 PV. COD and SS are performed by colorimetric (NF EN ISO 7393-2 2000) and gravimetric methods respectively (NF T 90 - 009 1986). The heavy metals are measured by Inductively Coupled Spectrometry (ICP) type Ultima 2- Jobinyvon. 
Table 1

Physico-chemical, metallic and bacteriological characterization of water

\begin{tabular}{|c|c|c|c|}
\hline DW & GW & TW & $\begin{array}{l}\text { Tolerable limits for concrete } \\
\text { application }\end{array}$ \\
\hline
\end{tabular}

((EN 1008 2003; ASTM C94

1996 ; EPA 2012)

\section{Physico-chemical}

\begin{tabular}{|c|c|c|c|c|}
\hline $\mathrm{T}^{\circ} \mathrm{C}$ & 21 & 24 & 15.5 & 35 \\
\hline $\mathrm{Ph}$ & 7.67 & 6.29 & 8.8 & \\
\hline $\mathrm{g}\left(\mu \mathrm{S} . \mathrm{cm} \nabla^{1}\right)$ & 1490 & 1322 & 2890 & $\geq 4$ \\
\hline MES (mg. Lख') & & & 29.5 & $\begin{array}{l}50000 \leq 1 \% \text { of the total } \\
\text { amount } \\
\text { of concrete aggregate. }\end{array}$ \\
\hline $\mathrm{NO}^{2-\left(\mathrm{mg} . \mathbb{W}^{\prime}\right)}$ & 12.34 & 18.09 & 16.02 & \\
\hline NO3- (mg.『1) & 10.79 & 16.53 & 20.61 & $\leq 500$ \\
\hline $\mathrm{SO} 4^{\left.2-(\mathrm{mg} . \mathrm{L})^{\prime}\right)}$ & 14.89 & 21.98 & 25.85 & $\leq 2000 \leq 3000$ \\
\hline H3PO4 (mg. Lه') & $\varangle 0.01$ & $\llbracket 0.01$ & 10.176 & 100 \\
\hline Cl-(mg. L区') & 95.85 & 110.02 & 158.45 & $\leq 500 \leq 500$ \\
\hline DCO mg02/L & & & 131.1 & \\
\hline \multicolumn{5}{|c|}{ Metal characterization } \\
\hline $\mathrm{Ca}$ & 73.48 & 356.53 & 63.08 & \multirow{4}{*}{$\begin{array}{l}\text { Combined total } \\
<2000\end{array}$} \\
\hline $\mathrm{Na}$ & 93.95 & 515.5 & 100.11 & \\
\hline K & 6.04 & 60.45 & 15.023 & \\
\hline $\mathbf{M g}$ & 50.09 & 49.75 & 50.076 & \\
\hline $\mathrm{Pb}$ & & & & $\leq 100 \mathrm{mg} / \mathrm{L}$ \\
\hline $\mathrm{Fe}$ & 0.12 & 8.63 & 0.31 & \\
\hline $\mathrm{Zn}$ & 0.37 & 0.13 & 0.15 & $\leq 100 \mathrm{mg} / \mathrm{L}$ \\
\hline \multicolumn{5}{|l|}{$\begin{array}{l}\text { Bacteriological } \\
\text { characterization }\end{array}$} \\
\hline \multicolumn{5}{|l|}{ DB05 mg 02 /L } \\
\hline CT & $\begin{array}{l}4 \\
\text { UFC/100 } \\
\text { MI }\end{array}$ & $\begin{array}{l}15 \\
\text { NPP/100mL }\end{array}$ & $\begin{array}{l}445 \\
\text { UFC/ } 100 \\
\mathrm{~mL}\end{array}$ & \ 20000 \\
\hline
\end{tabular}




\begin{tabular}{|c|c|c|c|c|}
\hline & DW & GW & TW & $\begin{array}{l}\text { Tolerable limits for concrete } \\
\text { application } \\
\text { ((EN } 1008 \text { 2003; ASTM C94 } \\
1996 \text {; EPA 2012) }\end{array}$ \\
\hline CF (E. coli) & & $\begin{array}{l}3 \\
\mathrm{NPP} / 100 \mathrm{~mL}\end{array}$ & $\begin{array}{l}98 \text { UFC/100 } \\
\mathrm{mL}\end{array}$ & $\otimes 200$ \\
\hline
\end{tabular}

Tables 1 shows the physico-chemical, metallic and bacteriological characterization of the waters studied. The analysis of the studied waters shows that drinking water and groundwater are almost neutral. While the treated wastewater is slightly basic and carries a biodegradable organic load (COD / BOD 5 ratio less than 3) (ONEP 1998). Their total concentration of solid substances (MES) complies with the mentioned specifications and range from $37 \mathrm{mg} / \mathrm{L}$ to $82 \mathrm{mg} / \mathrm{L}$, with an average of $59.5 \mathrm{mg} / \mathrm{L}$; this value could not affect the tempering of concrete. Concentrations of chloride, phosphorus, nitrate, sulfate, lead, zinc and iron are below the maximum allowable limits in EN 1008 (2003) and ASTM C94 (1996).

As for the fecal load of all the waters studied, it is almost nil. However, we note a low presence of Escherichia coli for treated wastewater that could be removed by simple purification before use. As for the groundwater, it is rich in iron but does not exceed the limit detrimental to the strength of the concrete (40 $000 \mathrm{mg} / \mathrm{L})$. Overall, the results of the analyzes of treated wastewater samples indicate that its composition comply with the limits allowed by the standards for a use in concrete (EN 1008 2003; ASTM C94 1996).

\section{Cement}

The cement used for the manufacturing of the test specimens is a CPI CEM II class $42.5 \mathrm{~N}$ type Portland cement from Lafarge-Holcim factory in Fes. It has been characterized by two BRUKER S8 TIGER and OXFORD MDX 1080 fluorescence spectrometers measuring chemical parameters ( $\mathrm{SO} 3$ sulfur trioxide, SiO2 total silica, Fe2O3 iron oxide, Al2O3 alumina, $\mathrm{CaO}$ lime, MgO magnesia, $\mathrm{Cl}^{-}$chloride, Sodium Oxide $\mathrm{Na} 2 \mathrm{O}$, and Potassium Oxide K2O) and physical parameters (Loss on ignition LOI, Insoluble residue RI, Withdrawal, Blaine fineness, Start of setting, Heat Stability, Compressive strengths at 2 days Rc2j and at 28 days Rc28j) according to the standards N.M 10.1.004 (2003).

Table 2

Composition of cement out of gypsum

\begin{tabular}{|llll|}
\hline Material & Limestone & Secondary constituent & Clinker \\
\hline Rate in \% & $<32$ & $<3$ & $>65$ \\
\hline NM 10.1.004 & $<35$ & $<5$ & $>65 \&<94$ \\
\hline
\end{tabular}

Table 3

Chemical characteristics of CPJ 45 cement

\begin{tabular}{|llllllllll|}
\hline Settings & $\mathrm{SiO}_{2}$ & $\mathrm{Fe}_{2} \mathrm{O}_{3}$ & $\mathrm{Al}_{2} \mathrm{O}_{3}$ & $\mathrm{CaO}$ & $\mathrm{MgO}$ & $\mathrm{Cl}^{-}$ & $\mathrm{Na}_{2} \mathrm{O}$ & $\mathrm{K}_{2} \mathrm{O}$ & $\mathrm{SO}_{3}$ \\
\hline Rate in \% & 17.77 & 2.55 & 4.32 & 57.96 & 1.14 & 0.07 & 0.08 & 0.37 & 2.39 \\
\hline N.M.10.1.004 a) & $* *$ & $* \star$ & $* *$ & $* \star$ & $<4$ & 0,10 & $* *$ & $* *$ & $<3$ \\
\hline
\end{tabular}


Table 4

Physical and Mechanical Characteristics of CPJ 45 Cement

\begin{tabular}{|lllllllll|}
\hline & LOI & RI & $\begin{array}{l}\text { Withdrawal } \\
(\mu \mathrm{m} / \mathrm{m})\end{array}$ & $\begin{array}{l}\text { Blaine } \\
\text { fineness } \\
\left(\mathrm{cm}^{2} / \mathrm{g}\right)\end{array}$ & $\begin{array}{l}\text { Start of } \\
\text { setting } \\
(\mathrm{mn})\end{array}$ & $\begin{array}{l}\text { Heat } \\
\text { stability } \\
(\mathrm{mm})\end{array}$ & $\begin{array}{l}\text { Rc2j } \\
(\mathrm{MPa})\end{array}$ & $\begin{array}{l}\text { Rc28j } \\
(\mathrm{MPa})\end{array}$ \\
\hline $\begin{array}{l}\text { Cement CPJ } \\
\mathbf{4 5}\end{array}$ & 13.26 & 3.8548 & $<800$ & $>4000$ & $>110$ & $<5$ & $* *$ & 37 \\
$\begin{array}{l}\text { N.M.10.1.004 } \\
\text { a) }\end{array}$ & $* *$ & $* *$ & $\leq 800$ & $\geq 2200$ & $\geq 90$ & $\leq 10$ & $\geq 12$ & $\geq$ \\
\hline
\end{tabular}

\section{The Aggregates}

Four types of aggregates were used; sand Wadi Ferkla and crushing sand, $8 / 16$ and 16/20 gravels that were supplied from the Zaim quarry. The sand used is a combination of various proportions of different fineness modules. The sand of Oued Ferkla (MF $=1.04)$ is thinner than crushing sand $(M F=3.89)$.

All aggregates were granulometrically analyzed. Their characterization was carried out according to the following standards NF P 18-553(1990), NF P 18-554(1990), NF P 18-555(1990), NF P 18-560(1990), NF P 18-573(1990), NF P 18-597(1990) and NF P 18-598(1991) by AG sieve size analysis, PS surface cleanness determination, CA flattening coefficient, ES sand equivalent test, the VB methylene blue test, the Ab absorption test, and the Los Angeles LA test. Figure 1 gives the results of the particle size analysis performed on the materials used. These results indicate that Wadi sand is composed of a majority of fine grains (98.4\%) with a diameter of less than $0.63 \mathrm{~mm}$, and that of crushing sand does not exceed $32.4 \%$. In order to adjust the fineness module to the quality standards of a good formulation, we have calculated the mixing proportions of each sand: $31 \%$ of crushed sand $0 / 5$ and $9 \%$ of fine sand of Wadi ferkla $0 / 4$. The actual granular class of the other aggregates is $8 / 16 \mathrm{~mm}$ crushed gravel and $16 / 20 \mathrm{~mm}$ for crushed gravel GII. The results of the physicochemical characterization of the different aggregates are illustrated in Table 5.

Table 5

Physical characterization of aggregates

\begin{tabular}{|c|c|c|c|c|c|c|c|c|c|c|c|c|}
\hline $\begin{array}{l}\text { Nature } \\
\text { sample }\end{array}$ & $\begin{array}{l}\text { Sampling } \\
\text { place }\end{array}$ & $\begin{array}{l}\text { class } \\
\text { d/D }\end{array}$ & $\begin{array}{l}\rho_{\text {app }} \\
\left(t / m^{3}\right)\end{array}$ & $\begin{array}{l}\text { Prél } \\
\left(t / m^{3}\right)\end{array}$ & $\begin{array}{l}\%< \\
80 \mu m\end{array}$ & $\begin{array}{l}A b \\
\%\end{array}$ & $\begin{array}{l}\text { PS } \\
\%\end{array}$ & $\begin{array}{l}\text { CA } \\
\%\end{array}$ & $\begin{array}{l}\text { LA } \\
\%\end{array}$ & $\begin{array}{l}\text { MF } \\
\%\end{array}$ & $\begin{array}{l}\text { VB } \\
\%\end{array}$ & $\begin{array}{l}\text { ES } \\
\%\end{array}$ \\
\hline GI & \multirow{2}{*}{$\begin{array}{l}\text { Career } \\
\text { Zaim }\end{array}$} & $8 / 16$ & 1,41 & 2,76 & $* *$ & 0.6 & 0.63 & 11 & 17 & $* *$ & ** & ** \\
\hline GII & & $16 / 20$ & 1.39 & 2.74 & ** & 0.5 & 0.17 & 8 & 18 & $* *$ & ** & ** \\
\hline \multirow[t]{2}{*}{ Sand } & $\begin{array}{l}\text { Wadi } \\
\text { ferkla }\end{array}$ & $0 / 5$ & 1.57 & 2.60 & 0.2 & 1.5 & $* *$ & $* *$ & $\star *$ & 1.38 & 0.5 & 72 \\
\hline & $\begin{array}{l}\text { Crushed } \\
\text { sand }\end{array}$ & $0 / 4$ & 1.55 & 2.58 & 0.2 & 1.2 & $* *$ & $* *$ & $\star *$ & 3.89 & 1.5 & 70 \\
\hline \multicolumn{3}{|c|}{$\begin{array}{l}\text { Specification of the standard } \\
\text { NM. NM } 10.1 .271^{\text {b) }}\end{array}$} & $* *$ & $* *$ & $\triangle 12$ & $* *$ & $\nabla 25$ & $\frac{0}{35}$ & $\star *$ & ** & $\frac{\square}{70}$ & $* *$ \\
\hline
\end{tabular}

Note: a) From references N.M.10.1.004 (2003)

b) From references NM 10.1.271(2008) 


\section{Methods}

Concrete formulation was carried out using the Dreux Gorisse method (Dreux and Festa. 2002) which appears to be the most practical and most exploited method because it is based on experimental results. Thus, this method makes it possible to obtain coherent and exploitable results in a simple, efficient and fast manner. The granular mixture has been optimized so as to have a granulometric curve of the mixture as continuous as possible: improve the performance and the implementation of the concrete.

The water quantity is determined to approach the ratio $\mathrm{E} / \mathrm{C}=0.5$. Table 6 present the optimized concrete formulation used in this study. The concrete chosen for this study is a characteristic reference plain concrete B25 of the majority of existing structures, including sensitive structures (dams, nuclear power plants ...). After preparation of the reference mixture (water DW), two types of water were used to separate mixtures (water of the sheet and treated wastewater TW). The other components of the blends were kept constant, especially cement like those in the control except the type of water, which was added for each mixture. The mixer used for the manufacture of concrete is a concrete mixer inclined axis with a capacity of 30 liters. The implementation of the pouring of concrete is established according to standard NF P 18-404 (1981) in cylindrical test pieces (320 $\mathrm{mm}$ in height and $160 \mathrm{~mm}$ in diameter), while respecting the order of filling of the different aggregates, the mixing time, and the control of the workability properties of the mixed concrete.

After 24 hours of hardening, the test pieces were demolded and immersed in drinking water in a storing room at $95 \%$ humidity and $20^{\circ} \mathrm{C}$ until the time of the test. The concretes thus produced were characterized in the fresh state by measurement of setting time, density and slump, and in the cured state by measuring the compressive and tensile strengths at different curing time (7, 14, 28 and 90 days). The setting time is determined by the automatic Vicat apparatus according to standard NF EN 196-3 (2017), the Abrams cone collapse test was carried out according to the standard NF EN 12350-2 (2012). The tensile and compressive strengths are successively analyzed according to standards NF EN 12390-6 (2012) and NF EN 123903 (2003). The press used is a Digital Compressive testing machine "50-C3422" with an automatic cycle time and a maximum capacity of $1500 \mathrm{KN}$ in accordance with ASTM C39 2018.

Table 6

Composition of concrete mixture

\begin{tabular}{|lllllll|}
\hline Constituants & Wadi sand & Crushed sand & Gravette GI & Gravette GII & Cement & Water \\
& $\left(\mathrm{kg} / \mathrm{m}^{3}\right)$ & $\left(\mathrm{kg} / \mathrm{m}^{3}\right)$ & $\begin{array}{l}\left(\mathrm{kg} / \mathrm{m}^{3}\right) \\
\left(\mathrm{kg} / \mathrm{m}^{3}\right)\end{array}$ & $\begin{array}{l}\left(\mathrm{kg} / \mathrm{m}^{3}\right) \\
(\mathrm{L})\end{array}$ \\
\hline Dosage & 495 & 491 & 234 & 668 & 350 & 175 \\
\hline
\end{tabular}

\section{Results}

\section{Characteristics of fresh concretes}

\section{Setting time}


Fig. 3 shows a comparison of the setting times (initial and final) for three mixtures of mortars which have the same formulation and differ only by the mixing water. The results presented in Fig. 3 allows to deduce a slight increase in the initial setting time of cement pastes mixed with purified waste water (about 3\%) in comparison with those spoiled with drinking water while respecting the different standards (EN 10081990 and ASTM C94 1996) that limit the gap in less than one hour to $25 \%$.

The type of mixing water influences the setting time. Water from the source reduces the start time to about 2.7\%, which is acceptable according to the same standards (EN 10081990 and ASTM C94 1996). These results could be explained by the presence of nitrates that could react with sodium at the $\mathrm{pH}$ of the medium and slightly accelerate the hydration reaction; Sodium and nitrate has a promotion effect on the hydration of cement matrices at the pre-induction period. The same behavior has been reported in earlier work (Zheng et al. 2020). In addition, the slowing of the hydration of concrete mixed with the treated waste water appears to be due to the presence of orthophosphate ions which can be adsorbed on the surface of the cement particles while slowing down their dissolution (Dorozhkin 2009; Laniesse et al. 2020, Naamane et al. 2016). The setting delay obtained by the purified water is very useful for concreting, especially in hot weather in the city of Er-Rachidia, for the transport of long-distance concrete and concreting in large volume. We note that the beginnings of catch were reached between $7 \mathrm{~h} 18 \mathrm{mn}$ and $7 \mathrm{~h} 36 \mathrm{mn}$ whereas those of the ends were between 10h $24 \mathrm{mn}$ and 11h $02 \mathrm{mn}$.

\section{Measurement of slump}

The slump test of the low-fluid fresh concrete makes it possible to determine its consistency according to the type of water used. Substitution of drinking water by treated wastewater and groundwater reduces subsidence. The workability of concrete mixed with these waters was firm and marked a slump between 2.8 and $3 \mathrm{~cm}$, due to the presence of solids. The subsidence decreased in purified wastewater due to the spongy surface of the sludge particles having a high absorption capacity. A similar observation has been made in the previous literature (Gholamreza et al. 2017).

\section{Density of fresh concrete}

The different types of mixing water had a slight impact on the density of the fresh concrete, as indicated by the density variation of less than $1 \%$ between the concretes manufactured with GW (2.00) and the TW (1.99) and that made with the DW (1.98) as control concrete which are all slightly lower than that of the traditional concrete B25 which must have a density around 2,35, this slight difference of density for the concrete tempered with the water from the tablecloth could be due to the presence of iron. It can act as a filler of the microstructure of cement pastes by refining the pore structure and reducing the total porosity, thus increasing the density of the composite; due to the filling, up of pores by secondary C-S-H formation (Sikora et al. 2016).

\section{Characteristics of concretes in the hardened state}

\section{Compressive and tensile strength of hardened concretes}


Fig. 5 shows the influence of the mixing water (DW, GW and TW) on the splitting resistance of concretes at the age of 7, 14, 28 and 90 days of curing. The results show a regular increase in the splitting tensile strength with the increase of immersion time for all concretes whatever the type of mixing water used. The replacement of drinking water by wastewater treated in ordinary concrete increases its resistance compared to other concretes mixed with drinking water by 3.5\%, 12\% and $16 \%$ at 7 days, 28 days and 90 days of cure, respectively. On the other hand, the replacement of drinking water by groundwater increased the tensile strength by $3.5 \%$ at 7 days and by $7 \%$ at 90 days.

Fig. 6 and 7 shows the evolution of the compressive strength of the ordinary B25 concretes including the three types of mixing water used (DW, GW and TW) according to the age of preservation in drinking water. The results show that:

The compressive strength of all concretes used increases regularly with age and shows no drop. At the age of 7 days, the test pieces prepared by the treated waste and the drinking water have comparable compressive strengths and are slightly higher than that of the concrete mixed with the water of the water. At the age of 1 month (+ 28 days), the development of the mechanical resistance of concretes mixed with drinking water and groundwater was similar. The compressive strength of B25 concrete mixed with treated waste water is $16.36 \%$ higher than that of concrete mixed with drinking water.

- The comparative analysis of the concrete results mixed with GW and DW shows that the compressive resistances with GW are improved at the age of 28 days and 90 days. This could be explained by the concentration of iron in the GW which greatly increases the mechanical strength. Due to the filling effect of iron, with low permeability and a significant increase in strength after 28 days of hardening. The possible reason for this increase is that iron consumes and reduces the amount and size of $\mathrm{Ca}(\mathrm{OH}) 2$ crystals and fills voids in the CSH gel structure and ultimately the structure of hydrated products is denser and compact (Zhang et al. 2020; Umra Shettima et al. 2018; Vilazdeh Kiamahalleh et al. 2020). At the age of 90 days, the compressive strength is maximum in the specimens prepared with the treated wastewater. According to the literature, these results could be explained by the increase in the $\mathrm{pH}$ of the cementitious matrix due to the strong basicity of the TW and the high concentration of phosphate ions in this type of concrete, which precipitates calcium and calcium crystallize rapidly as hydroxyapatite preferentially to HSCs, according to the following equation (Valizadeh Kiamahalleh et al. 2020; FROHARD 2014):

$10 \mathrm{Ca}^{2+}+6 \mathrm{PO}_{4}^{3-}+2 \mathrm{OH}^{-} \rightarrow \mathrm{Ca}_{10}\left(\mathrm{PO}_{4}\right)_{6}(\mathrm{OH})_{2}$

As noted by Waddell (1974), a good measure of concrete quality could be obtained by using the ratio of 28day concrete strengths $\left(f_{T W 28}\right)$ to that of a similar mixture cast with potable water $\left(f_{d}\right)$. The ratio of $f_{T W 28} / f_{d}$ is 1.16 , which indicates that the 28-day compressive strength of concretes prepared with treated wastewater is $16 \%$ higher than that of concretes prepared with drinking water. The water of the water, the ratio of $f_{G W 28} /$ $f_{d}$ is 1.036 , thus indicating a $3.6 \%$ increase in the resistance to 28 days than that of DW. The results thus obtained favor the use of water treated wastewater from the Er-Rachidia wastewater treatment plant for the production of ordinary concrete as they significantly improved the development of B25 concrete resistance in 
the long term (28 days and more). Table 7 illustrates the compressive strengths and porosity at 60 days of concretes made with different types of mixing water.

As shown in Table 7, the porosity decreases with the increase of the compressive strength. Thus, concretes made with groundwater or treated wastewaters are less porous in comparison with those prepared by drinking water. This result might be explained by the formation of gypsum and ettringite that is more favored in the first case and that fill the voids left by the mixing water trapped in the pores and the capillaries of the concrete, which evaporates slowly with time. Thus, the effect of the type of mixing water used does not stop in the mechanical properties, it could also influence the porosity of the concretes and therefore its durability, since the rise of the porosity reduce the resistant of concrete.

Table 7 Resistance of mixed concrete with different types of water at 60 days and their porosity

\begin{tabular}{|llll|}
\hline & DW & GW & TW \\
\hline $\mathrm{Rc}_{60 ;}[\mathrm{MPa}] \pm 1 \mathrm{MPa}$ & 25 & 32.5 & 30 \\
\hline Porosity [\%] $\mathbf{0 0 , 5 \%}$ & 7.92 & 5.59 & 6.68 \\
\hline
\end{tabular}

\section{A one-way analysis of variance (ANOVA) test}

The Table. 8 presented the results of a Unidirectional Variance Analysis (ANOVA) test that was performed at a significant $5 \%$ compression resistance level at the ages of 7, 14, 28 and 90 days. There are three groups of concrete mixtures (DW, GW, and TW) and four samples for each group and age for analysis. To present the significance of the experimental results concisely, all concrete mixtures were compared together with the control mixture (DW). In the ANOVA test, if the P-value is greater than $5 \%$ in the $95 \%$ confidence interval, the difference between the results of various concrete mixtures is not significant. The results of the ANOVA statistical test at a $5 \%$ significance level showed no significant difference between the compressive strength of the concrete of various concrete mixtures at test ages with a probability value $p$ being below the threshold of significance of 0.05 and an $F$ value lower than the critical $F$ value.

It shows that the development of concrete with wastewater types studied in this research does not significantly affect. Thus, these types of treated wastewater can be used for the development of concrete offering better performance in terms of resistance to fractional traction.

Table 8 A one-way ANOVA at the significant $5 \%$ compressive strength of B25 concrete mixes using various types of water at 7, 14, 28 and 90 days of age. 


\begin{tabular}{|lllllll|}
\hline Descriptive statistics & & & & & & \\
& & & & & & \\
7 Days & 14 Days & 28 Days & 90 Days & N valide (listwise) \\
\hline N & statistics & 12 & 12 & 12 & 12 & 12 \\
\hline Minimum & statistics & 3.5 & 3.00 & 5.00 & 8.50 \\
\hline Maximum & statistics & 18.00 & 24.00 & 27.00 & 32.00 \\
\hline Medium & statistics & 21.50 & 27.00 & 32.00 & 40.00 \\
\hline Standard deviation & Statistics & 19.8658 & 25.3900 & 29.2142 & 36.0000 \\
\cline { 2 - 7 } & Statistics & 1.15664 & 1.13158 & 1.97497 & 3.12933 \\
\hline Variance & statistics & 1.338 & 1.280 & 3.900 & 9.793 \\
\hline
\end{tabular}

ONEWAY 7 Days,14 Days, 28 Days, 90 Days BY VAR00005

/POLYNOMIAL=1

/MISSING ANALYSIS.

\section{One-way ANOVA}

\begin{tabular}{|llclllll|}
\hline & Sum of squares & ddl & Standard Error & $\mathbf{F}$ & $\mathbf{F}_{\text {crit }}$ & $\begin{array}{l}\text { Signification } \\
\text { (p-value) }\end{array}$ \\
\hline One-way ANOVA & 14.716 & 11 & 1.338 & 10.874 & 13.753 & .000 \\
\hline One-way ANOVA & 14.085 & 11 & 2.12 & 10.604 & 17.33 & .000 \\
\hline One-way ANOVA & 42.905 & 11 & 1.77 & 34.634 & 59.23 & .000 \\
\hline One-way ANOVA & 107.720 & 11 & 1.985 & 95.891 & 70.45 & .000 \\
\hline
\end{tabular}

\section{Conclusion}

The use of the treated water of the Er-Rachidia wastewater treatment plant, as compared to groundwater and drinking water, has the following conclusions:

- Given the huge and sustainable availability, treated wastewater can potentially combat the scarcity of water.

- The analytical results of the quality of treated wastewater tested and the allowable limits of mixing water for concrete show that the TW is suitable for the production of concrete.

- The standard consistency of cement decreases by $4 \%$ and $20 \%$ for concretes spoiled respectively by purified wastewater and groundwater. 
- The different types of mixing water had a slight impact on the density of the fresh concrete which did not affect its quality in terms of resistance,

- Concretes tempered with treated wastewater indicate a slight increase in the initial and final setting times of the cement, which remains within the prescribed limits giving them good mechanical strength. This limits their use in ordinary concrete. However, this retardation will be very useful for hot-weather concreting, long-distance transport of concrete and mass concreting.

- The compressive strength shows that the type of mixing water has direct effects on the compressive strength, especially in the long term.

In conclusion, the recycling of treated wastewater in the mixing of ordinary concretes is a promising operation because it does improve their mechanical resistance ages ago. It does not, also, affect much the other parameters. Further research is needed because it would be much telling to study the durability of such materials to know their behavior over 3 months and the stability of all the chemical elements in the concrete. Throughout this study the substitution of drinking water by treated wastewater will help to minimize the need for its use. Moreover, it eliminates the need to expand the drinking water supply for use in the concrete industry. Furthermore, it increases the number of water treatment plants due to population growth. Additionally, it saves drinking water for consumption and makes wastewater treatment plants more economically attractive by reusing water before final treatment, together with other similar goals for sustainable development.

\section{Declarations}

Acknowledgements The authors gratefully acknowledge the financial support of the Ministry of Environment. We also thank Engineering Laboratory of Organometallic, Molecular Materials, and Environment, Faculty of Sciences Dhar El Mahraz, Sidi Mohamed Ben Abdellah University for supporting this project. Thanks also to any structure that contributed to the realization of this work thanks to their feedback and testimonies.

Authors' contributions F.Z. Bouaich: Writing - Original draft, Investigation, Formal analysis, Data curation; W. Maherzi: Writing - Revision \& editing, Formal analysis; F. El-hajjaji: Validation, Visualization, Revision \& editing; N. Abriak: Conceptualization, Visualization; M. Ben Zarzour: Formal analysis, Visualization; T. Mustapha: Conceptualization, Supervision, Visualization; Z. Rais: Methodology, Writing - Revision \& editing, Conceptualization, Supervision, Visualization.

Data availability The datasets used and/or analyzed during the current study are available from the corresponding author on reasonable request

\section{Compliance with ethical standards}

Conflict of interest The authors declare that they have no conflict of interest.

Ethical approval All procedures performed were in accordance with the ethical standards of the institutional and national research committee

Consent to participate All authors were participated in this work 
Consent to publish All authors agree to publish

\section{References}

1. ABH (2018) Update study of the Integrated Master Plan for the Water Resources of the Guir-Ziz-Rhéris and Maïder Basins 2018.

2. Actionnaires, L. A. U. X. (n.d.). L A FA RG E HOLC I M R A PPORT A NNUEL 2016. Retrieved June 23, 2019, from https://www.lafargeholcim.com/sites/lafargeholcim.com/files/atoms/files/03022017-financelafargeholcim_annual_report_2016-fr.pdf

3. Asadollahfardi G, Tahmasabi G, Nabi SM, Pouresfandyani H, Hossieni S. A. A (2017) Effects of using concrete wash water on a few characteristics of new concrete. Environmental Engineering and Management Journal, 16(7): 1569-1575.

4. ASTM C39 (2018) Standard test methods for the time of setting of hydraulic cement by Vicat Needle. ASTM International, West Conshohocken

5. ASTM C-94 (1996) Standard Specification for Ready mix Concrete.

6. Dorozhkin, S. V (2009) Calcium orthophosphate cements and concretes. Materials, 2(1), 221-291. https://doi.org/10.3390/ma2010221

7. Dreux, G, Festa J (2002) Nouveau guide du béton et de ses constituants, huitième édition. Editions Eyrolles. https://www.eyrolles.com/BTP/Livre/nouveau-guide-du-beton-et-de-ses-constituants9782212102314/

8. EPA. (2012) Guidlines for water reuse. Guidelines for Water Reuse, September. [EPA/625/R-04/108, chapter 3].

9. FROHARD F. (2014) Durability of eco-concrete: impact of alternative cement additions on the corrosion of reinforcements in reinforced concrete. 307.

10. Iso, P. N. M. Marocaine, N. (2006) Norme Marocaine Recherche.

11. KOSMATKA, Steven H, WILSON ML (2011) Design and Control of Concrete Mixtures - The Guide to Applications, Methods and Materials.

12. Kucche KJ, Jamkar SS, Sadgir PA (2015) Quality of Water for Making Concrete: A Review of. International Journal of Scientific and Research Publications. 5(1): 1-10.

13. Laniesse P, Cau Dit Coumes C, Le Saout G, Mesbah A. (2020) Understanding the setting and hardening process of wollastonite-based brushite cement. Part 1: Influence of the $\mathrm{Ca} / \mathrm{P}$ ratio and H3PO4 concentration of the mixing solution. Cement and Concrete Research, 134: 106094 https://doi.org/10.1016/j.cemconres.2020.106094

14. Naamane S, Rais Z, Taleb M (2016) The effectiveness of the incineration of sewage sludge on the evolution of physicochemical and mechanical properties of Portland cement. Construction and Building Materials. 112: 783-789. https://doi.org/10.1016/j.conbuildmat.2016.02.121

15. NF P 18-554 December (1990) Granulats- Mesure des Masses Volumiques, de la porosité, du coefficient d'absorption et de la teneur en eau des gravillons et cailloux.

16. NF EN 1008 Juillet 2003. (n.d.). Retrieved June 23, 2019. 
17. NF EN 12350-2 Juin (2019) Essais pour béton frais - Partie 2 : essai d’affaissement.

18. NF EN 12390-3- Juin 2019 Essai pour béton durci « Partie 3 : Résistance à la compression des éprouvettes».

19. NF EN 12390-6 - Avril (2012) Essais pour béton durci - Partie 6 : détermination de la résistance en traction par fendage d'éprouvettes.

20. NF EN 196-3-Septembre 2017. n.d. Accessed June 24. (2019) .

21. NF EN ISO 7393-2- Mars 2000. (n.d.). Retrieved June 24, (2019).

22. NF P 18-573-Décembre (1990) Granulats- Essai Los-Angeles.

23. NF P 18-553 - Septembre 1990. Granulats- Préparation d'un échantillon pour essai.

24. NF P 18-555 - Décembre 1990. Granulats- Mesure des Masses Volumiques, coefficient d'absorption et de la teneur en eau de sables.

25. NF P 18-560 - Septembre 1990. Granulats- Analyse granulométrique par tamisage.

26. NF P 18-597 - Décembre 1990. Granulats- Détermination de la propreté des sables : équivalent de sable à $10 \%$ de fines.

27. NF P 18-598- Octobre 1991. Granulats- Détermination de la propreté des sables : équivalent de sable à $10 \%$ de fines.

28. NF P18-404 - Décembre 1981. (n.d.). Retrieved June 24, 2019.

29. NF T 90-009- Septembre 1986. Essais des eaux - Dosage des ions sulfate - Méthode gravimétrique (Indice de classement : T90-009).

30. NM 10.1.008 (1990) - Béton de ciments usuels.

31. NM 10.1.271 (2008) Granulats pour bétons hydrauliques_Définitions, Spécifications, Conformité.

32. ONEP (1998) Approach to the typology of urban wastewater in Morocco. ONEP et GTZ. Rabat.

33. Renaud P, Chartier S, \& Kaufman, D. (2008). Perceptual constancy and the dynamics of extracting perceptual Visual invariants in virtual immersion. In Proceedings of the 5th IASTED International Conference on Signal Processing, Pattern Recognition, and Applications, SPPRA 2008. https://doi.org/10.4135/9781412975704.n88

34. Sarrazin J, Lafarge, S. (2011) Le béton, une solution pour la construction durable.

35. Sikora P, Horszczaruk E, Cendrowski K, Mijowska E (2016) The Influence of Nano-Fe304 on the Microstructure and Mechanical Properties of Cementitious Composites. Nanoscale Research Letters. 11(1): 1-9. https://doi.org/10.1186/s11671-016-1401-1

36. Umara Shettima A, Ahmad Y, Warid Hussin M, Zakari Muhammad N, Eziekel Babatude O (2018) Strength and Microstructure of Concrete with Iron Ore Tailings as Replacement for River Sand. E3S Web of Conferences. 34: 1-9. https://doi.org/10.1051/e3sconf/20183401003

37. Valizadeh Kiamahalleh M, Alishah A, Yousefi F, Hojjati Astani S, Gholampour A, Valizadeh Kiamahalleh M (2020) Iron oxide nanoparticle incorporated cement mortar composite: correlation between physicochemical and physico-mechanical properties. Materials Advances. 1(6): 1835-1840. https://doi.org/10.1039/d0ma00295j 
38. WWAP (2018) World Water Assessment Programme (Nations Unies) (2018), The United Nations World Water Development Report 2018 (United Nations Educational, Scientific and Cultural Organization, New York, United States) www.unwater.org/publications/ world-water-development-report-2018/.

39. Zhang W, Gu X, Qiu J, Liu J, Zhao Y, Li X. (2020) Effects of iron ore tailings on the compressive strength and permeability of ultra-highperformance concrete. Construction and Building Materials, 260:119917. https://doi.org/10.1016/j.conbuildmat.2020.119917

40. Zheng Z, Li Y, Zhang Z, Ma X (2020) The impacts of sodium nitrate on hydration and microstructure of Portland cement and the leaching behavior of Sr2+. Journal of Hazardous Materials. 388: 121805. https://doi.org/10.1016/j.jhazmat.2019.121805.

\section{Figures}

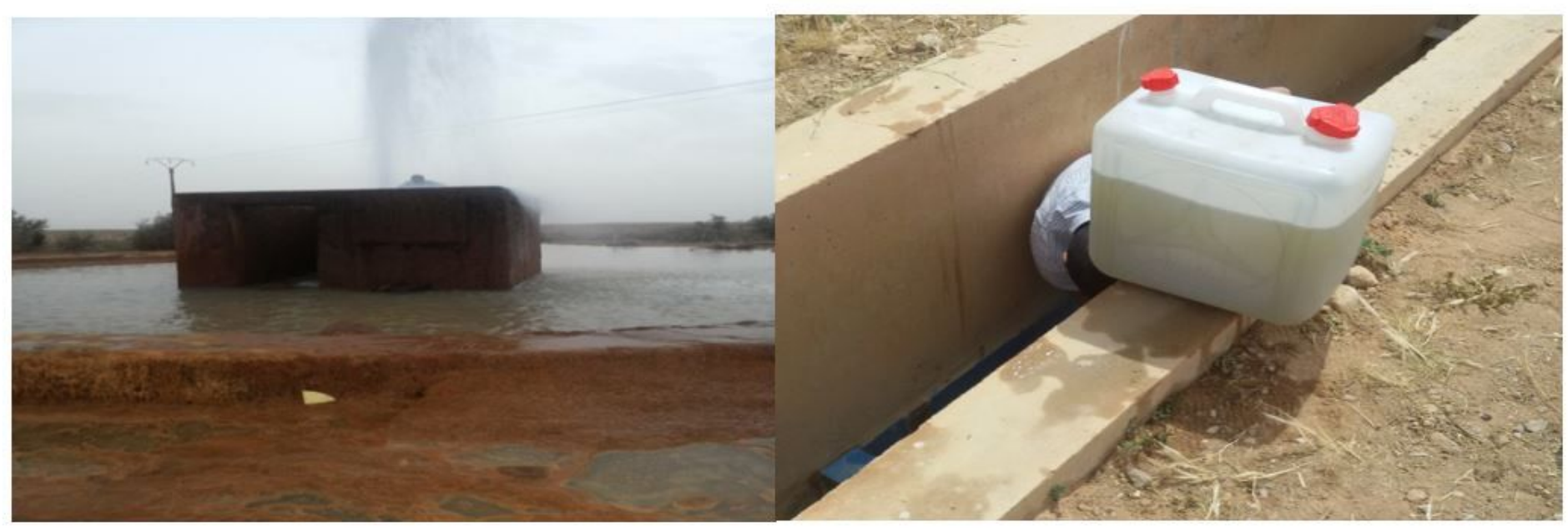

\section{Figure 1}

a) Groundwaters of the Aïn El Atti artesian b) wastewater treatment plant. 


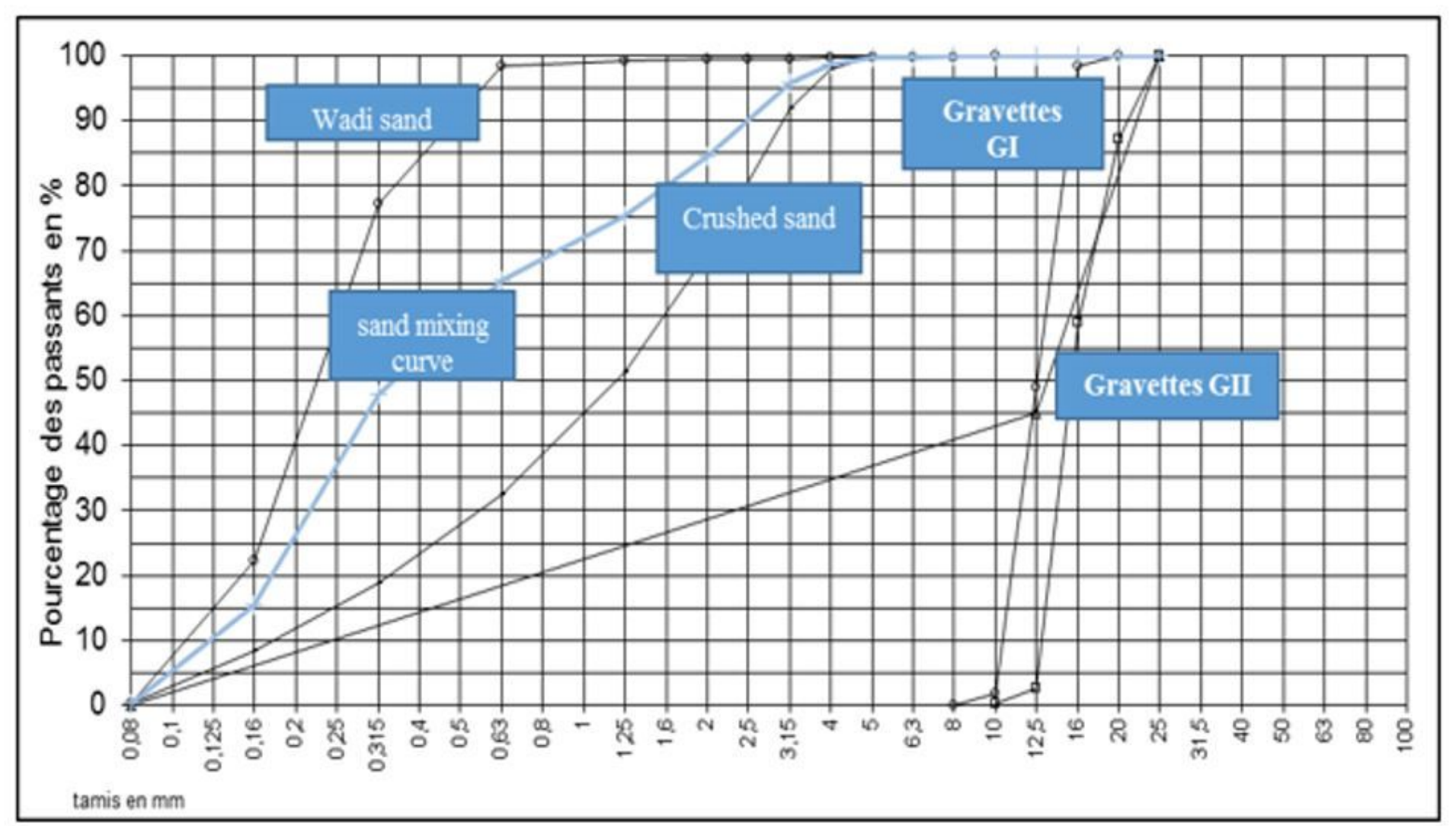

Figure 2

Particle size distribution. 


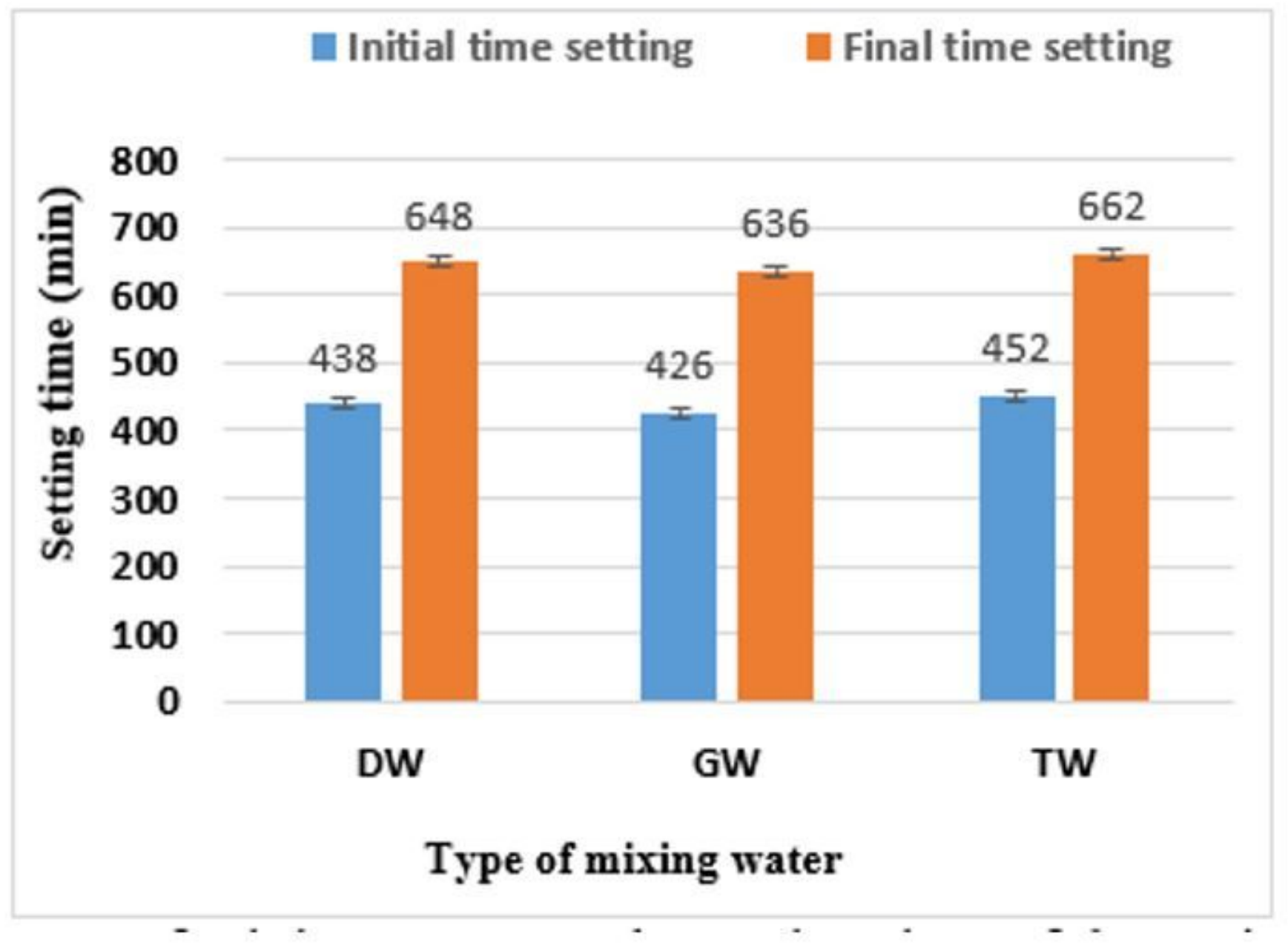

Figure 3

Effect of the type of mixing water on the setting time of the various concrete 


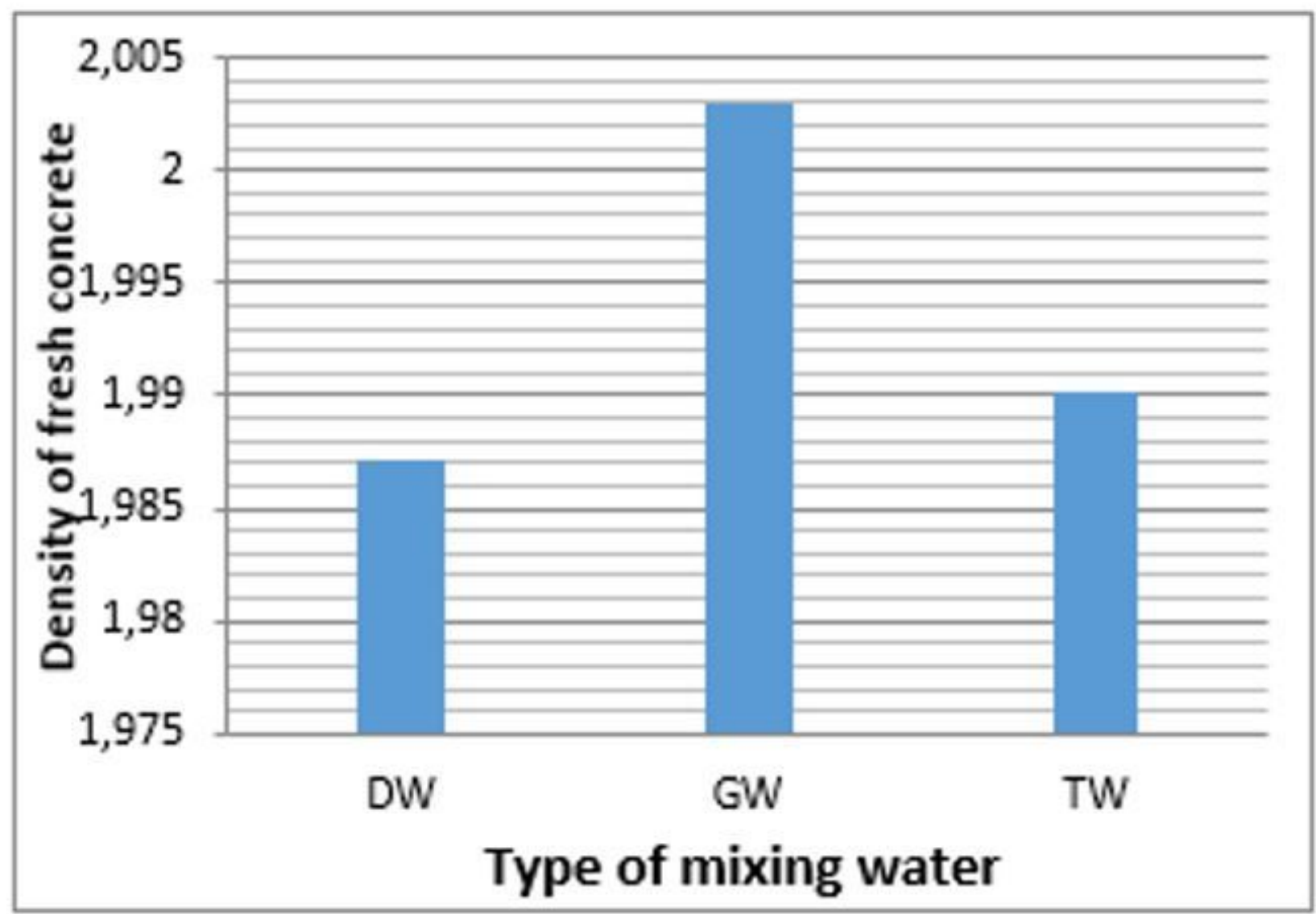

Figure 4

Effect of the type of mixing water on the density of fresh concrete 


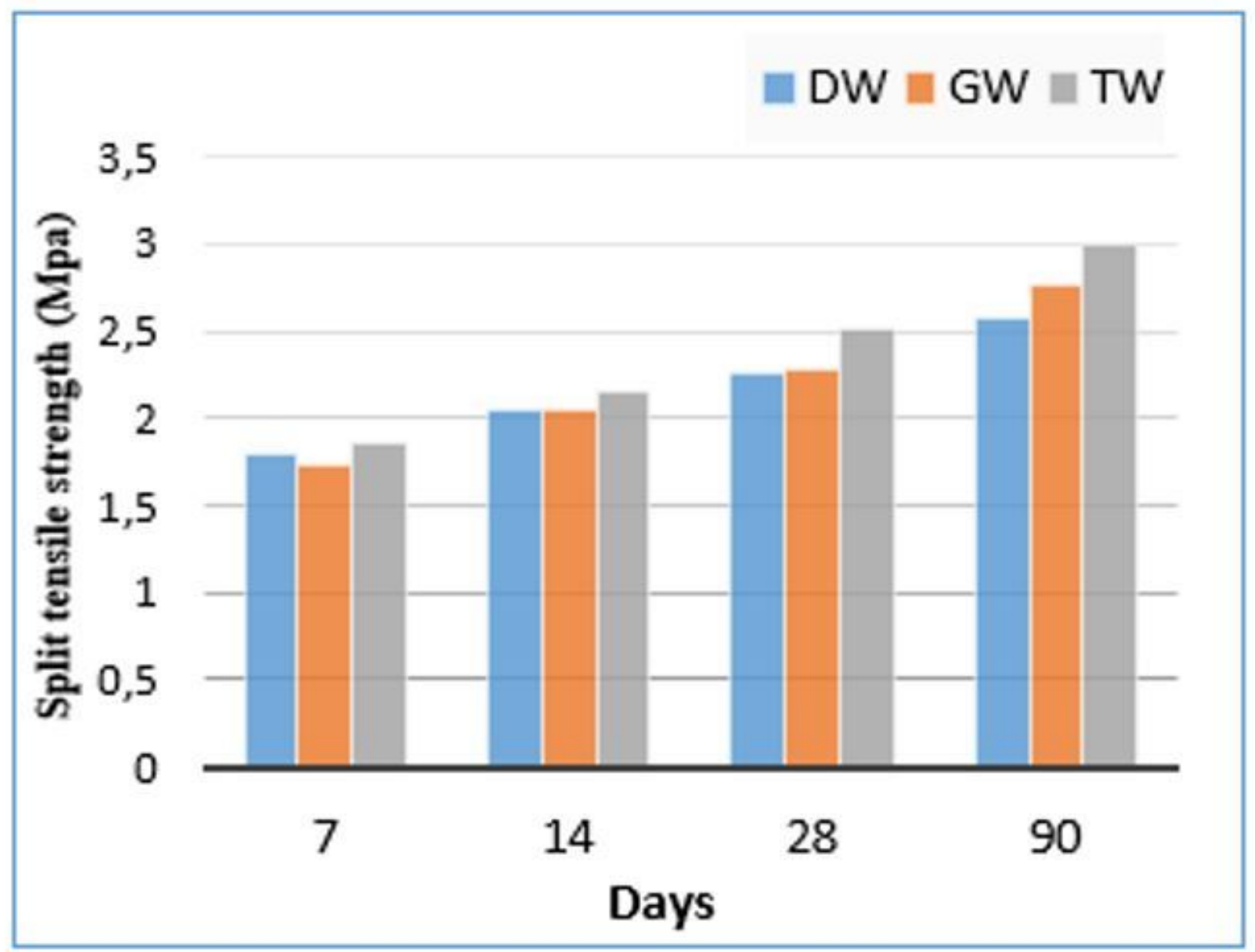

Figure 5

Split tensile strength of all concrete mixes at different curing time 


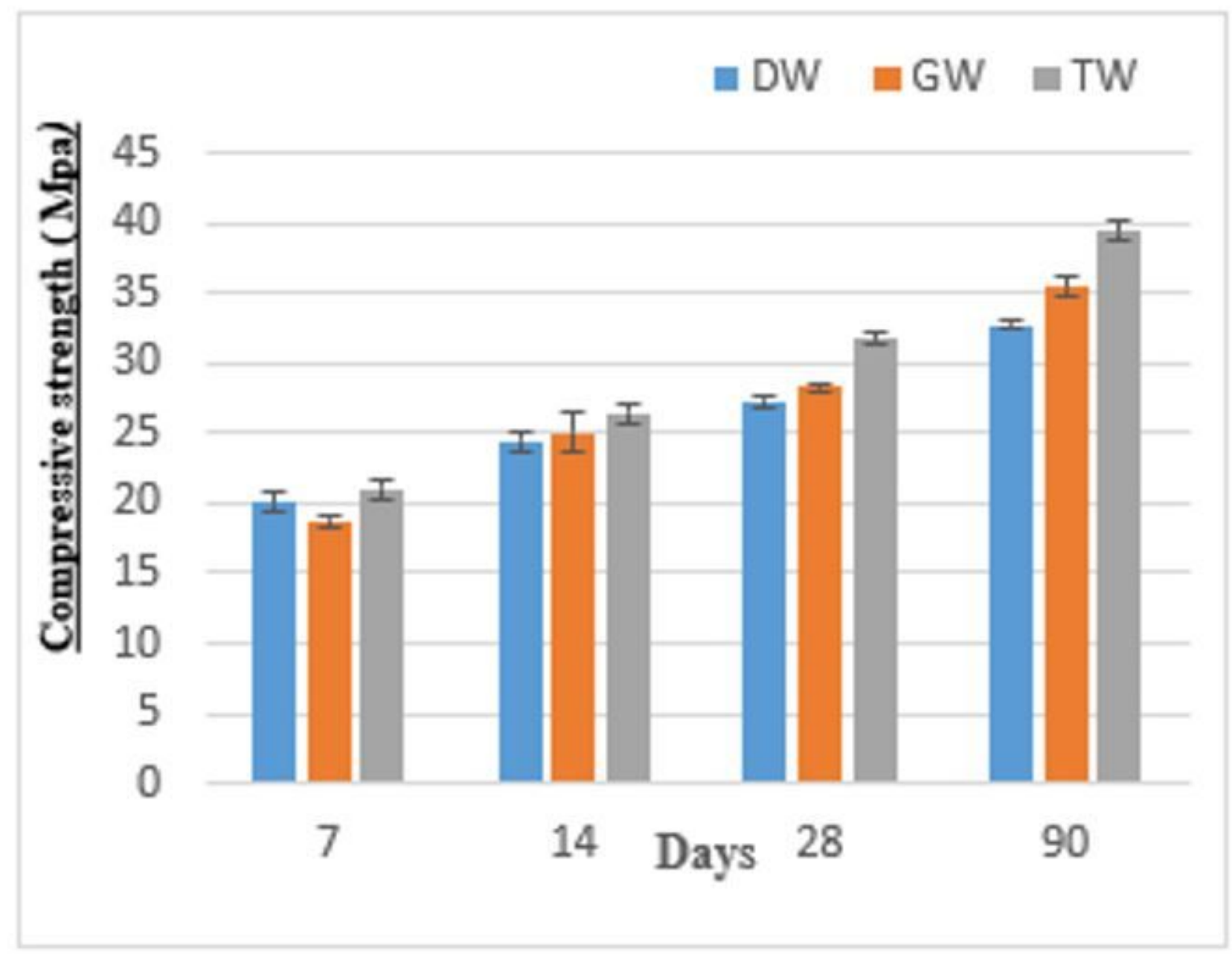

Figure 6

Compressive strength of concrete at different curing time 


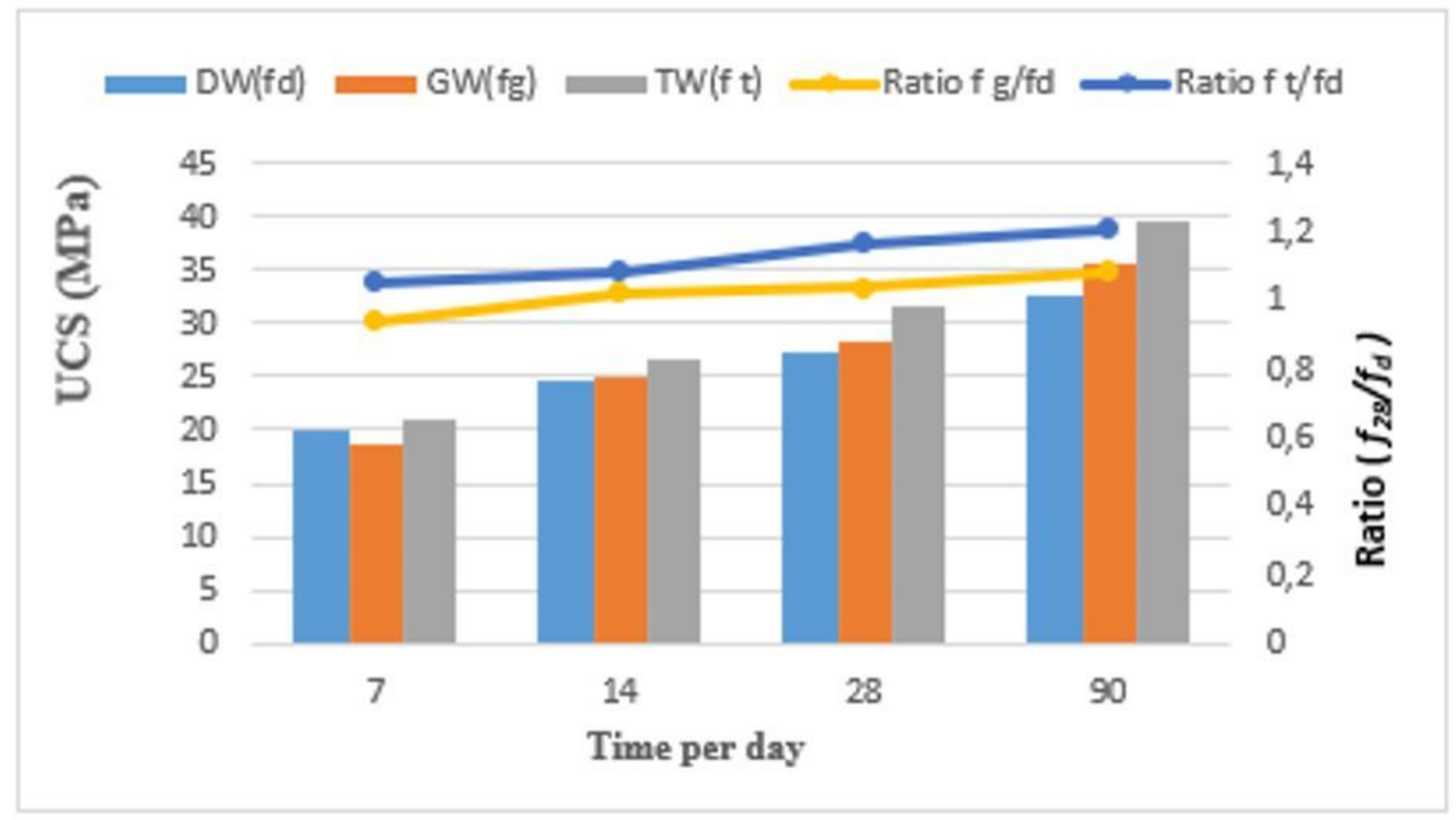

Figure 7

Strength of concrete at different curing time 